\title{
3
}

\section{Citizenship and Authority: A Chastened View of Citizenship}

My purpose in this essay is to present and defend what I think of as a chastened view of citizenship. "Chastened" means subdued or tempered as compared with some alternative understanding that is more enthusiastic, celebratory, or evangelical in tone and character. Because this essay is addressed primarily to professional political scientists, and because the most influential recent discussions of citizenship in the political science literature could hardly be called celebratory, characterization of my view as chastened needs immediate explanation. Chastened as opposed to what?

We can make a (rough) beginning by adverting to the familiar distinction between empirical and normative theories. Much recent writing about citizenship-for example, the works of Schumpeter, Downs, Lipset, Berelson and his associates, Dahl, Sartori ${ }^{1}$ —adopts something like the following stance: the "classical" ideal of citizenship, deriving from such daunting personages as Pericles, Aristotle, and Rousseau, elevates citizenship to the highest moral and political standing. Citizens are free, equal, and engaged with one another in pursuing matters of high and distinctively human import. Citizen-

1See Joseph Schumpeter, Capitalism, Socialism, and Democracy, 4th ed. (New York: Harper \& Row, I954); Anthony Downs, An Economic Theory of Democracy (New York: Harper \& Row, I957); Seymour Martin Lipset, Political Man (Garden City, N.Y.: Doubleday, I960); Bernard Berelson et al., Voting (Chicago: University of Chicago Press, I954); Robert Dahl, A Preface to Democratic Theory (Chicago: University of Chicago Press, 1963), Pluralist Democracy in the United States (Chicago: University of Chicago Press, 1967), After the Revolution (New Haven: Yale University Press, 1970), and Polyarchy (New Haven: Yale University Press, 197I); Giovanni Sartori, Democratic Theory (New York: Praeger, 1965). 


\section{Toward a Liberalism}

ship is the distinctive human activity and the distinctively important feature of a political society. Whatever the merits of this ideal from a normative perspective (most of the recent writers just mentioned, one surmises, do not rate them very highly), the ideal is unachievable in and hence irrelevant to political life and practice in the modern nation-state. The continuous, intense, morally uplifting interactions that the ideal presumes can obtain, if at all, only in and among subgroups within the large, complex, and impersonal societies of the modern world. Attempts to achieve and sustain such interactions at the level of the political society are distracting and destabilizing. Accordingly, political scientists must resolutely set the classical ideal aside and investigate the realities of and realistic possibilities for citizenship in the political societies of our day. The empirically grounded descriptions and prescriptions that result, uninspiring though they may be, will have the greater merits of accuracy and realism.

These "empirical" accounts and theories of democracy and citizenship are not chastened in the sense I intend here. Rather than temper or refine the classical theories against which they are (in part) reactions, they abandon the normative objectives and commitments characteristic of the latter. They are less a chastened species of an explicitly normative genus than a covertly moralistic species of an allegedly empirical or scientific genus.

The prevalence of these notionally scientific theories of citizenship has (along with numerous other factors) spurred a revival of insistently normative theorizing that takes its bearings from the classical theories of Aristotle and Rousseau. Writers such as Arendt, Barber, Pateman, Thompson, and Walzer ${ }^{2}$ have insisted that the fundamentally normative questions raised by the classical theories cannot be disposed of by showing that the practice of those contemporary societies conventionally labeled democratic do not comport

2See Hannah Arendt, The Human Condition (Garden City, N.Y.: Doubleday, 1959), Between Past and Future (New York: Viking, 196I), and On Revolution (New York: Viking, I963); Benjamin R. Barber, The Death of Communal Liberty (Princeton: Princeton University Press, 1974), Superman and Common Men (New York: Penguin, I97I), and Strong Democracy (Berkeley: University of California Press, I984); Carole Pateman, Participation and Democratic Theory (Cambridge: Cambridge University Press, 1970), and The Problem of Political Obligation (Berkeley: University of California Press, I979); Dennis F. Thompson, The Democratic Citizen (Cambridge: Cambridge University Press, I 970), and Political Participation (Washington, D.C.: American Political Science Association, 1977); Michael Walzer, Obligations (Cambridge: Harvard University Press, I970) and Radical Principles (New York: Basic Books, I980). 
with any of the versions of the classical ideal. If practice does not satisfy ideal, we must conclude not that ideal should be scrapped but that practice is unsatisfactory and should be changed. Several of the recent revivalists of the classical ideal, moreover, insist that the ideal is much more compatible with, could be much more fully realized in and by, contemporary societies than "scientific" critics of that ideal contend. ${ }^{3}$

It is by comparison with the classical ideal and its recent revivals and restatements that the view presented here is chastened. Insofar as the "normative-empirical" distinction can be sustained, I agree that the normative issues raised by the classical view cannot be settled by adducing some set of alleged facts about modern societies. If (I) there were such a thing as a set of ideal-neutral factual observations, or such a thing as an "empirical theory" that was independent of ideals, if (2) those facts or that empirical theory were discrepant from the classical ideal, but (3) the ideal were nevertheless normatively superior, then our task would be to attempt to alter the facts. It would fall to us to act politically and morally to try to bring the facts and hence the empirical theory into conformity with the ideal. Or at least it would fall to us to lament the discrepancy between the two. As my sometime colleague Ralph Lerner used to say, we may be swept down the stream, but we are not therefore obliged to shout hosannas to the gods of the river.

Of course clauses (I) and (2) in the previous paragraph are patently counterfactual. Leaving aside general questions in the philosophies of meaning, theory construction, and scientific method, no reader of studies and theories of democracy such as Berelson's Lipset's, or Sartori's can fail to see that those works are imbued by moral and political values and preferences sharply at variance with those that inform the thought of Aristotle and Rousseau. More fundamentally, no student of the moral and political practices over which these theories claim to generalize can fail to see that the participants in those practices accept and act upon a set of beliefs and values which, while residually influenced by the classical ideal of citizenship, include understandings and orientations difficult to accommodate to the classical ideal. ${ }^{4}$ The notion that we could study

${ }^{3}$ See esp. Thompson, Democratic Citizen; Pateman, Participation and Democratic Theory; Barber, Strong Democracy.

${ }^{4}$ See Gabriel Almond and Sidney Verba, The Civic Culture (Princeton: Princeton University Press, 1963); J. David Greenstone and Paul E. Peterson, Race and Authority in Urban Politics (Chicago: University of Chicago Press, I973). 
and theorize about democracy and citizenship without addressing the normative issues raised by the classical ideal is no better than a more or less willful misunderstanding.

The present view, then, is intended to be chastened in the sense that it seeks to temper the moral and political ideal of citizenship that comes down to us from the deepest thinkers on the subject. It addresses the question of whether the third of the above subjunctive clauses is counterfactual; whether the beliefs and values that constitute that ideal deserve our reflected allegiance. It is intended, moreover, to be chastened, not antagonistic. The initial, the immediate, moral appeal of the Aristotelian and, on some readings, Rousseauean variants of the classical ideal seems to me undeniable. There is even reason to doubt whether a self-respecting human being could justifiably accommodate to a politically organized society that is not committed to and that does not substantially realize the values and objectives of this ideal of citizenship. To put this point another way, it is not surprising that many of those who have rejected the Aristotelian view have been led to a strongly antipolitical stance. Even the most scrupulously chastened-as opposed, again, to antagonistic - view of the ideal of high citizenship tends toward a political withdrawalism, the fully developed expression of which is now philosophical anarchism. ${ }^{5}$ One way to state the question that will concern me is to ask whether this tendency can be arrested; whether a stable, ratiocinatively defensible position can be established between a politics of high citizenship and a non- or antipolitical stance. I suggest possibilities along this line. But we should note that to put the matter this way is to assume that anarchism or other extreme versions of withdrawalism are not choiceworthy and hence that the classical ideal of citizenship must be tempered, not rejected or abandoned. I am not able to defend this assumption systematically in this essay, but I try to say something concerning it.

As indicated by the title of this essay, I address these questions by attending to the relationship between citizenship and authority. A step toward doing so can be taken by recalling a well-established position-namely, Plato's - which is distinct from both the high

${ }^{5}$ Of course withdrawalism was not anarchistic in its most notable premodern expressions. Political withdrawalists such as the Stoics, Augustine, Pascal, Montaigne, and Hobbes found it possible to be in but no more than marginally of (as opposed to against) their political societies, a position revived by recent libertarian thinkers and, to my mind more interestingly, by Michael Oakeshott. 


\section{Citizenship and Authority}

citizenship argument of Aristotle and withdrawalist views such as those of the Stoics, Pascal, and nineteenth- and twentieth-century anarchists. No one would accuse Plato of amoral scientism in his thinking about politics. For Plato, active, vigorous political arrangements and processes are indispensable to the well-being of all but the most superior members of the human race. Yet for all save those superior few (who take on an active political role as a painful duty), human beings should be subjects not citizens. Their well-being will be achieved by submitting to the moral-cum-political authority of the philosopher-kings. A political society that accords anything like citizenship to any very large segment of its populace is unjust in itself and will of certainty produce severe instability and moral degeneration. The choice is not between a politics of high citizenship and withdrawal from political society; it is between a political order that fosters moral excellence through the proper distribution and exercise of authority and a moral and political disorder in which the many are encouraged to meddle in matters beyond their ken.

In its insistently anticitizenship Platonic version, this understanding is no more a serious contender for the intellectual allegiance of the twentieth-century political mind than is philosophical anarchism. Few among us would accept Plato's identification of justice with a society employing a division of labor in which significant moral and political decision making is the all but exclusive prerogative of a narrow elite. As attenuated as citizenship has become in even those societies of our time with some justification for their selfdesignations as democratic, not many of their members would exchange the values of citizenship for the stability, order, economic efficiency, or other desiderata said to be the yield of all but entire subordination to-what Plato was prepared to call-political authority.

The Platonic view is nevertheless important for my present purposes. This is so generically because it presents insistently normative arguments against citizenship; it is important specifically because the arguments it presents invoke authority and subordination to authority as essential elements in a proper moral and political order. It is made to appear that the moral values and objectives of political society are to be achieved not by interaction among citizens but by the subordination of subjects to those who are deservedly in possession of public authority. We are to think about political society and 


\section{Toward a Liberalism}

its moral characteristics and objectives not in an undifferentiated manner as if all members or participants contribute to those objectives in the same ways, but in terms of highly organized specializations of function and insistently hierarchical patterns of superiority, subordination, and deference.

From Aristotle on, much of the argumentation for high citizenship has been in reaction to the Platonic understanding. Sharing the objectives of moral excellence in human life, and sharing the conviction that an organized political society is at least a necessary condition of such excellence, proponents of such citizenship have tried to show that the excellence can be achieved-perhaps can only be achieved-in a politics of citizenship as distinct from and opposed to a politics of authority on the Platonic model. By defining citizens as persons who are equal in the sense that they share in offices and who rule and are ruled in turn, ${ }^{6}$ and by celebrating political societies characterized by citizenship in this sense, Aristotle at least appears to have banished (what Plato had taught him to regard as) authority to the private realm. He believed that Plato was correct that the naturally, the necessarily, superior should rule over the naturally inferior. Masters should rule over slaves, parents should rule over children, husbands over wives. But politics occurs in the realm of freedom not of necessity; at its best, political life takes place among persons who have no claim to Platonic authority over one another. When Rousseau said that in a proper political society "every person while uniting himself with all ... obeys only himself and remains as free as before," 7 he restated, in radically democratized form, this same understanding, this same opposition between a politics of citizenship and a politics of authority.

Whatever we may think of its epistemological foundations, Plato's position depends on an untenable, indeed an incoherent, conception of authority. The notion he seeks to articulate is of authority in the sense of someone who is an authority concerning a subject matter--for example, Corwin as an authority on the United States Constitution or Samuel Beer as an authority on British politics. Plato is correct that this notion presupposes a sharply drawn inequality between those who are authorities and those who are not. Corwin is an authority concerning constitutional law because

${ }^{6}$ Aristotle, Politics, I 275b, I 279 a.

${ }^{7}$ Jean Jacques Rousseau, The Social Contract (New York: E. P. Dutton, I950), I, vi. 


\section{Citizenship and Authority}

he knows more about that subject matter than most others who are interested in it. But because the latter must be able to recognize the superiority of Corwin's knowledge, at least some among them must know a good deal about it. Authority, even of the kind Plato sought to delineate, involves a relationship not just with the subject matter on which one is an authority but between the person (a) who is an authority and those others persons (b) for whom (a) has that standing. Keen to establish the unqualified superiority of philosopherkings, Plato made it impossible for them to attain or sustain authority as opposed to power or domination. ${ }^{8}$

The foregoing criticism of Plato's understanding of authority is important to my attempt to find stable conceptual and normative ground between the ideal of high citizenship and political withdrawalism. My more immediate concern is with an incoherence into which, by the wrongheaded brilliance of his formulations, Plato induced the partisans of high citizenship who reacted against him. If Plato had been correct that authority and citizenship are incompatible, then a politics of citizenship would have to exclude authority. But this is an impossibility. Citizenship, I argue, presupposes authority. Those "offices" in which the Aristotelian citizen shares are established by rules (for example, the rules of a constitution) which are themselves invested with authority and which invest the offices and their officeholders with that same property. That "ruling and being ruled in turn" which defines the Aristotelian citizen would be incomprehensible apart from laws and commands that, once adopted, are binding on rulers and ruled alike because invested with authority accepted by both. However the array of offices may have been decided on, through whatever process it may have been invested with authority, a citizen dissatisfied with it must accommodate to that array unless and until it has been changed by established procedures-by procedures themselves invested with authority. In the same way, a citizen discontent with a law or command must obey it until those whose turn it is to rule-which of course may include the dissenter-have seen fit to repeal or alter it. In both cases the "must" in question is an obligation of citizenship, one that is supported by sanctions that may include the loss of the status of citizen itself. In the absence of such authority, the notion of citizen-

8I have elaborated the understanding of authority that informs this criticism of Plato (and much of the discussion in this essay) in The Practice of Political Authority (Chicago: University of Chicago Press, 1980). 


\section{Toward a Liberalism}

ship has the echoing political emptiness of the phrase "citizen of the world."

As these remarks indicate, it would be overstating the case to assert that proponents of high citizenship propose, implicitly or explicitly, to eliminate public authority altogether. However we resolve the controversy about the presence or absence of the concept of authority in Aristotle, he is not only aware but insistent that citizens rule one another. ${ }^{9}$ Nor can there be any doubt that the decisions of the Sovereign of Rousseau's Social Contract bind all citizens until those decisions have been changed; or, for that matter, that the decisions of what he calls government bind the citizenry until such time as the latter have acted as Sovereign to override those decisions. Something akin to authority is and must be at work in at least these respects.

An adequate treatment of these matters will require some refinements concerning the concept of authority. Leaving these refinements to later sections, it remains the case that my discussion thus far commits no worse than an exaggeration. The politics of high citizenship is intended to be sharply contrasted with a politics of authority. Interactions among citizens are distinctive just in that they are interactions among equals; they are among persons who have no binding authority over one another in respect to the subject matters of their interactions as citizens. And it is this interaction itself that is distinctively valuable. Familiar sociological language may help us here. There is a kind of recognition that citizenship is a status or office defined by rules that are invested with authority. But the more powerful tendency is to think of it as a role rather than as a status. There are proprieties and improprieties in the performance of the role; indeed it is through the identification of those proprieties, through delineation of the notion of citizenship, that theorists of high citizenship give expression to some of their deepest values. These proprieties, however, are to be defined less by legal rules invested with authority than by customs and conventions that develop in the course of the interactions and by moral principles derived from thinking about the objectives and purposes distinctive

9I am thinking of Hannah Arendt's argument that there is no genuine, differentiated concept of political authority in either Plato or Aristotle, that the concept was an invention of the Romans. See her "What Is Authority?" in Between Past and Future. See also Elizabeth Anscombe, "Modern Moral Philosophy," in Ethics, ed. Judith J. Thomson and Gerald Dworkin (New York: Harper \& Row, I968). 
to the role itself. Salient among those objectives and purposes is the aim of fostering interaction as little inhibited as possible by authority. The thought seems to be that success in pursuing this objective will reduce authority (over and among citizens) to the minimal possible proportions.

No one suspicious of or wary about authority will be insensitive to the appeal of this understanding. Even if one is skeptical (as I have been and remain) concerning the project of seeking a moral transformation of human beings through a politics of high citizenship, one can appreciate the ways in which active citizenship can improve the quality of the decisions reached and can limit the excesses to which political authority-and its all but invariable handmaiden, political power-has shown itself to be prone. But if I am correct that citizenship is itself inseparable from authority, if a commitment to citizenship is itself a commitment to some species of political authority as a feature of one's political arrangements, then the very considerations that lead one to value citizenship are also reasons for tempering one's enthusiasm for it. If authority is objectionable, and if citizenship does not come without authority, then citizenship cannot be an unalloyed good.

Such at least is the thought I explore in these pages. I propose to reexamine the ideal of high citizenship in light of the relationship between that ideal and a political phenomenon, authority, about which proponents of the ideal have themselves been ambivalent if not skeptical. This program requires closer attention to authority than is usual in the literature concerning citizenship; ${ }^{10}$ it requires an attempt to articulate and to assess the complex relationships among the suppositions, elements, and implications of both authority and citizenship.

\section{Types of Authority}

There are two main types of authority and two basic kinds of argumentation supporting a place for authority in a political association. ${ }^{11}$ The first type has been called by a variety of names,

10An exception is Dahl's After the Revolution.

11I elaborate the following distinctions in The Practice of Political Authority. See also Richard B. Friedman, "On the Concept of Authority in Political Philosophy," in Concepts in Social and Political Philosophy, ed. Richard E. Flathman (New York: Macmillan, 1973). 
including "substantive" and "personal" authority. It is perhaps most clearly exemplified by a person who is an authority on a subject matter such as a body of knowledge or an activity. Arguments for authority of this kind in politics are presented in Plato's thought, in Thomism and some other moral and political doctrines substantially influenced by religious dogma, in Marxism, and by sociological theories of a strongly functionalist bent. I have elsewhere called political theories that are primarily about and that argue for authority of this kind "substantive-purpose" (S-P) theories. The second main type is often called "positional" or "formal" authority. Authority of this kind is most familiar to us as vested in an office and thereby accruing to the holders of that office. Persons who hold such an office are therefore in authority; that is, they are invested with authority to make certain decisions whether they are an authority on the subject matters that the decisions concern. Max Weber's discussion of "rational-legal" as opposed to "charismatic" and "traditional" authority is one of the most influential treatments of formal authority. ${ }^{12}$ Forceful arguments for it are to be found in Thomas Hobbes, in the tradition of the rule of law as opposed to men (especially in the theory of the so-called Rechtsstaat), and most recently and powerfully in the writings of Michael Oakeshott. ${ }^{13}$ I refer to theories of this type as formal-procedural (F-P) theories.

\section{Substantive Authority}

Arguments for personal or substantive authority typically have a large factual dimension. They involve propositions of the form "It is the case that ..." and frequently "By nature ..." or "In the nature of things ..." It is the case that Charles Goren knows more about the game of bridge than most other people. In the nature of things there are classes of human beings who are fitted for reflection and for rule, thers for military service, for household or menial work, and for being ruled. These propositions, which in principle are supportable by evidence about what is indeed the case, establish (claim to establish) differences or inequalities that are the basis of the distinction between those who possess authority and those who do not. These inequalities are a.distinctive feature, perhaps the distinctive feature, of authority of this type. The truth of some such

12See the selections from Weber in ibid.

13See esp. Oakeshott's On Human Conduct (Oxford: Clarendon Press, 1975). 


\section{Citizenship and Authority}

propositions is therefore a necessary condition of authority of this kind being justified, and the belief that some proposition of this kind is true is a necessary condition of any person actually achieving the standing of an authority concerning any particular subject matter or activity.

The existence or believed existence of such a factual inequality, however, is not a sufficient condition for either the existence or the justified existence of personal authority. I might concede that there are philosophers who know more about morals and politics than I do and yet insist that personal authority has no proper place in political life. Perhaps making and learning from mistakes is regarded as integral to the pleasure of the game of bridge. Perhaps I think that a politics in which decisions are made by authority destroys or derogates from the dignity or autonomy of those who accept that arrangement. As already indicated, to be an authority is to stand in a distinctive relationship not just with a subject matter or activity but with other persons who are interested or involved in it. The latter must recognize, accept, accede to, that relationship. And a justification for authority of this type must take account of the significance of that relationship for those who are party to it. It is interesting to note that even Plato accepts a version of this understanding. He seems to think that the superior wisdom and goodness of philosophers is itself sufficient to justify, though not of course to establish or sustain, the political subordination of nonphilosophers. In the peculiar ontological-cum-deontological manner in which he uses the term justice, such subordination is just in itself and needs no further justification. (Of course he also believes that the subordination is to the advantage of the nonphilosophers.) But the task of ruling is worse than merely uncongenial or distasteful to the philosophers; it is unnatural in that it forces them to return to the cave of appearance and opinion. Thus there is an ontological wrong involved in requiring philosophers to be kings, a wrong that cannot be justified by the sheer superiority of the philosophers. Accordingly, both Plato and his opponents must supplement their claim that there is in fact inequality with further arguments for basing authority on it. ${ }^{14}$

A great many such arguments have been offered. Of those with

${ }^{14}$ It is primarily because Plato describes subjects as incapable of understanding and acting on such further argumentation that authority-as distinct from power or domination-is an impossibility in his theory. 


\section{Toward a Liberalism}

which I am familar, all are instrumental in character. Some end will be attained, some good will be achieved, some value served, by including relationships in terms of personal authority among the arrangements and practices of the society or group. That good or value-among political writers justice, stability, order, efficiency, and community have been among the favorites-is of sufficient importance to justify what would otherwise be objectionable aspects of authority relations. In short, a tradeoff is proposed. The philosopher-kings give up some of the elevation and nobility of a life in communion with the good in order to contribute to the justice and well-being of all of the members of their society (or perhaps they give up some of the nobility that they wish for in exchange for a measure of protection against the demos); free, autonomous persons give up some of their freedom and autonomy in order to obtain material well-being, substantive justice, security, or stability.

Owing to this combination of characteristics, the argument for substantive authority can be attacked by objecting to either its factual or its instrumental premise. The classical exponents of the ideal of high citizenship, who have without exception opposed any very large role for personal authority among citizens, have done so primarily by attacking the factual premise. As we have seen, Aristotle accepts Plato's view that some human beings are by nature fit to rule, some only fit to be ruled. But he diminishes the qualities or characteristics necessary in order to be fit for rule, thereby enlarging, as against Plato, the number of those who fall into that category. By the same move, he largely rejects Plato's view that personal or substantive authority has a proper place in political life. Political life occurs among citizens; all citizens are equal in the sense of being eligible for or fit to rule; therefore no citizen is entitled to personal authority over any other citizen. In a society featuring the politics of high citizenship, personal authority is largely if not entirely banished to the private realms in which the requisite inequality obtains. Rousseau's theory of citizenship involves an analogous move. He does not, however, so much lower the requirements for participation in rule as change their content from the primarily cognitive capacities and attainments insisted on by Plato to moral or dispositional characteristics. And he contends not that all in fact possess those characteristics but that participation in a properly ordered political society will itself develop the characteristics in all (adult males) who engage in it. (Substantive authority does retain what 
might be called a protopolitical role in the vital activities of that Platonic figure who haunts the Social Contract, the Legislator who establishes-and sustains? - Rousseau's ideal political society.)

These moves by theorists of high citizenship, however, produced difficulties of a high order of theoretical complexity and practical significance. These difficulties may have contributed importantly to the emergence of formal or positional authority in politics, and in any case realization of them did much to foster the development of F-P theories of authority. But neither the practice nor the theory of formal authority resolved the difficulties, and they continue to beset both thought and action concerning citizenship and authority. I will first identify the difficulties as they present themselves in Aristotle's uncertain movements toward a formal-procedural theory of authority and then look at some of the more salient moments in the later history of attempts to deal with them.

In rejecting, as regards politics, the premise of a natural inequality that justifies the rule of some citizens over others, Aristotle's theory of high citizenship abandons what seems then to have been the only accepted foundation for political authority. ${ }^{15}$ But this leaves Aristotle in a difficult position. On his understanding of politics, including the politics of high citizenship, political life does involve ruling and being ruled. But as already suggested here, it is difficult if not impossible to invoke these notions without also invoking, however implicitly, some mode or kind of authority. Holding that tyranny is rule exclusively in the interest of the ruler, Aristotle does not make the modern equation between rule without authority and tyranny. ${ }^{16}$ Yet ruling and being ruled have to be distinguished from other forms of superiority and subordination, dominance and submission. Drawing this distinction requires a theory of the nature and basis of authority. In other words, Aristotle has left himself with political authority for which he lacks a satisfactory basis or justification.

\section{Formal Authority}

Insofar as he recognizes and tries to resolve this difficulty, Aristotle does so by forseeing, albeit dimly, the possibility of a formal concept of authority and by foreshadowing later F-P arguments for

${ }^{15} \mathrm{Cf}$. the discussions cited in n. 9, above.

16See Politics, I 279a et seq. 


\section{Toward a Liberalism}

its instrumental value. As in all F-P theories, his argument begins with the premise that equality (in relevant respects) obtains among those party to the authority relationship. Citizens are equal to one another in the sense that each of them possesses those qualities and characteristics requisite to participation in the ruling of the polis. In terms I have already used, citizens are equal in that each of them participates in the offices of the polis and thereby "rules and is ruled in turn." These famous formulae anticipate the later understanding that persons otherwise equal to one another could nevertheless be in authority over one another by virtue of having acceded to an office invested with formal authority. Acceding to such an office did not assume, and consistent with the premise of natural equality, could not be allowed to have created, personal superiority of the kinds that yield standing as an authority. Rather, justifications for the authority had to respect the foundational assumption of the equality of citizens.

A certain discomfort with this situation on Aristotle's part may already be intimated by the formula that citizens rule and are ruled in turn. True, Aristotle suggests that this arrangement itself contributes to the telos of political life. Learning to be ruled is said to be part of learning to rule. ${ }^{17}$ But even if we allow him this somewhat unspecified notion, it remains unclear why the process of learning to be ruled cannot be completed at a relatively early age, thereby allowing all mature citizens to rule themselves continuously rather than intermittently. ${ }^{18}$ If politics is conceived of as an activity through which development toward the fully and distinctively human end is achieved, any limitations on full participation qualify the ideal in unacceptable ways. Insofar as reliance on offices of authority creates divisions of labor or specializations of function, those excluded, however temporarily, from some tasks must thereby be deprived of some of the distinctive benefits of political life. Thus when Aristotle says that citizens rule and are ruled in turn, it looks as if he is trying to give the most favorable appearance to an arrangement that he knows to be discrepant from the ideal he is advancing.

It was of course Rousseau who sought to remedy this defect in the

17Ibid., I 277b.

18To put this difficulty somewhat differently and in a manner that anticipates discussion below of a further problem, if a citizen hasn't already learned to be ruled, how can that citizen safely be permitted to participate in ruling? 


\section{Citizenship and Authority}

ideal of high citizenship. His emphatic rejection of representation 19 is, among other things, a rejection of the notion of a distinct office or set of offices invested with the authority to act on behalf of - that is, to rule over-those not occupying that office or those offices. All citizens must participate equally and continuously in all of the actions of the Sovereign. But there is a further difficulty in reconciling offices invested with formal authority with the ideal of high citizenship. I have noted Aristotle's acceptance of Plato's view that politics have the high moral purpose of making it possible for citizens to achieve a morally excellent life. ${ }^{20}$ Of course Aristotle thinks of morals and politics as practical not theoretical sciences, indicating thereby his rejection of Plato's view that incorrigible or undeniable truths can be attained concerning the good life. ${ }^{21} \mathrm{He}$ nevertheless holds firmly to the conviction that morals and politics allow better as opposed to worse understandings, superior as opposed to inferior judgments and conduct. And while he dismisses the view that there are infallible philosopher-kings, he believes with equal firmness that there are some who are morally and politically wiser, who consistently (dispositionally) choose and act in a morally and politically superior manner. ${ }^{22}$ Because the class "morally and politically wiser" does not coincide with the class "citizens," 23 the arrangement by which all citizens rule and are ruled in turn seems to guarantee periods in which the morally and politically less wise will rule over those who are wiser than they.

Awareness of this difficulty may inform Aristotle's discussions of the good man versus the good citizen and the practical versus the contemplative life, ${ }^{24}$ discussions that with hindsight might even be read as anticipating the reflections of political withdrawalists such as Montaigne and Pascal. The truly superior person, the person capable of the fully contemplative life, will not participate in politics. At the end of this essay I suggest a quite different interpretation of these among Aristotle's discussions, one that may help in arriving at a defensible conception of citizenship and political participation. However this may be, there is undeniably a tension (one we will

${ }^{19}$ Rousseau, Social Contract, II, i.

20Aristotle, Politics, I 278b, I 282 b.

${ }^{21}$ Aristotle, Nicomachean Ethics, I I 40a-43a.

${ }^{22}$ Ibid., I I 04 b-43a.

23 Or rather, the two coincide only under an ideal constitution: Politics, III, iv.

${ }^{24}$ Ibid., VII, iii; I, ii; Nichomachean Ethics, IX, ix; I, vii. 
encounter again) between the procedural aspects of Aristotle's theory of high citizenship and its substantive or moral purposes. This tension compounds and deepens the more general difficulty of reconciling authority and high citizenship. In addition to limiting participation itself, it appears that including offices of formal authority within the arrangements of a polis will allow the morally less wise to rule over the morally wiser. Insofar as it is the objective of high citizenship to achieve the morally good life among the members of a society, it is not easy to see how this arrangement can be justified.

I consider Aristotle's responses to these objections below. But first I want to note a kind of justification that, while almost certainly not intended by Aristotle, might be read into his discussion. The formula "rule and ruled in turn" suggests at least that offices of authority circulate among citizens over time, perhaps even that all citizens occupy one or more among the array of offices at any given moment in time. We have to qualify somewhat the ideal of fully and continuously equal participation in political life, but we attempt to do so fairly or equitably. The sense of the fairness of the arrangement, moreover, might be augmented somewhat by the following consideration: perhaps Able disapproves of Baker's decisions during the latter's tenure in office. But because Able can look forward to her own turn as holder of that office, it is unreasonable for her to object to the arrangement. Perhaps Able can reverse Baker's decisions or undo the effects of Baker's actions. Even if such steps are impracticable, Able can take comfort, perhaps even satisfaction, in the thought that Baker will like Able's rule no better than Able liked Baker's. The outcome of this arrangement may not otherwise be very edifying, but the reciprocity it involves makes it fair and to that degree justified.

These last thoughts are not in the idiom characteristic of Aristotle the theorist of high citizenship. (Of course high citizenship is not Aristotle's sole moral or political concern and its vocabulary is not his exclusive moral and political diction-a caveat that must be entered with respect to this entire discussion.) Read in the perspective of later discussions of citizenship and authority, they do evoke familiar images and set by now conventional reflections in motion. Acceptance of offices of formal authority does qualify and require compromises concerning the attributes and objectives distinctive of citizenship. But because the same qualifications are required of all citizens, because the qualifications are distributed fairly or justly 


\section{Citizenship and Authority}

and maintained reciprocally among the entire citizenry, it is reasonable for each citizen to agree to them.

\section{Authority as Authorization}

To understand the notion of reasonable agreement to a just arrangement of offices of authority we must consider a subtype of authority relations not obviously classifiable as either substantive or formal. This subtype is represented by the concept "authorization." In the simplest case, I authorize you to act on my behalf, to be my agent, to represent me. This arrangement may involve elements of personal or substantive authority. I may authorize you to represent me in part because I believe that you are an authority concerning the matters with which you will deal in acting on my behalf. Once again, however, we need more than the premise of inequality. My belief that you deserve standing as an authority is neither a necessary nor a sufficient condition of the relationship in question. I may give authorization to a person who lacks standing as an authority and I may withhold it from a person who deserves that standing. At the same time, the arrangment involves some of the elements of formal authority. You do not occupy an office in the sense of a position in a hierarchy that may remain constant through changes in officeholders, and thus far your "jurisdiction" is limited to me. But my authorization itself permits you, within the scope of the authority I have accorded you, to bind me to what may be a considerable array of performances. If I dislike the content of your actions, I may withdraw my authorization. But my assessment of the merits of those of your actions that are within the authority I have accorded you is, at least often, irrelevant to my obligation to perform as you have committed me to do.

In the simple case I am discussing, your authority and the authority relation between us are less a feature of a collectivity than a personal, even a private relationship. This feature of the arrangement, especially the fact that your authority results directly from, is limited by, and terminates with the withdrawal of my authorization, may do much to make it attractive to me. Clearly I have more control over the arrangement than is available to me in the more collective, institutionalized arrangements characteristic of political authority. If political authority could be founded on such authorizations, the qualifications effected against the ideal of equal citizen- 
ship would be justified not merely by the fact that they apply equitably but by the further fact that they would arise from and depend on each party's decision or choice.

Before developing the significance of these considerations for the concerns of this essay, it will be well to put them in perspective by noting that authorizations commonly acquire important social, public, and even legal characteristics that constrain the conduct of those who are party to them. In some cases they become practices in the sense exemplified by law and medicine. If I engage a lawyer to represent me, our relationship takes its character not merely from my authorization but from the customs and conventions, and indeed the legal rules, that surround and to some extent govern the conduct of lawyers and their relationships with clients. Although my lawyer as such does not hold an office with a specified authority and jurisdiction, she does occupy a social status and does play a socially and in part legally defined role. The norms and rules that define and govern her status and role place restrictions and requirements on her relationships with me and her actions on my behalf. Thus despite the fact that my lawyer's authority depends on my authorization, I cannot hope to have entire control over her authority in relation to me.

The attractions of authority relations based on authorizations have nevertheless been considerable. Because each such relationship requires an authorization from the person or persons over whom the authority will be held and exercised, the arrangement appears to accord a measure of respect to the basic equality that is fundamental to the ideal of high citizenship. Regardless of the distribution of authority that has been made in a society, all members remain equal in the fundamental sense that each is under authority by her own decision or choice. And even if authorizations are made in part in recognition of inequality in respect to a particular subject matter or activity, equality in respect to actions concerning that subject matter can in principle be reasserted at any time. Moreover, in all other respects the presupposition of equality remains unqualified.

In light of these considerations we cannot be surprised at the recurrence of efforts to build other more specifically political modes of authority on the foundation of individual authorizations. At least from Hobbes, the classic versions of consent and contractarian theories of authority have followed this path. The chief and remark- 
ably constant suppositions of the theory are closely similar to those I "read into" Aristotle's discussion of ruling and being ruled in turn. Citizens (or in Hobbes's case subjects) are equal one to the other in that no one of them is sufficiently superior in morally and politically relevant respects to be entitled to personal authority over any others. "By nature" or "in the nature of things" the only authority that is politically germane is the authority that each person has over her own decisions and actions. Political authority can be justified only if it takes its origins from authorizations through which equal individuals transfer some of their authority over themselves to some other agent or agency. If such authorizations are given, and if they yield a distribution of authority and correlative obligations that is fair, then political authority can be justified.

\section{Reconciling Authority and Citizenship}

The consensus on these points, of course, coexists with very sharp disagreement on vital questions about the relationship between citizenship and authority. Debate concerning these questions, which has been waged from Hobbes to the present, can be viewed as a continuing attempt to resolve tensions already evident in Aristotle's theory of citizenship. Very roughly, the debate is between Hobbes and his (in respects to be discussed) followers on the one hand and Rousseau and later Rousseaueans on the other. The former give explicit and insistent development to Aristotle's foreshadowing of the notion of formal authority and embrace the inference that any very high citizenship is incompatible with authority and everything that depends on it. The imperative generated by the fact of natural moral equality is more or less fully satisfied by consent to the creation of offices of authority. From the moment of that consent on, ruling is and ought to be done primarily by those invested with that authority. The latter, proponents of high citizenship, may allow that authority can be created, perhaps that it can only be created, in this way. Individual consent or authorization provides a solution to the problem of how offices invested with binding authority-above all the office of citizen-can be justified. These theorists, however, insist on high citizenship and they struggle to reconcile their commitment to that ideal with their own acceptance of formal authority grounded in a collection of authorizations. 


\section{Toward a Liberalism}

Aristotle and Hobbes

I proceed by examining Hobbes's classic version of the first of these modes of argumentation. I argued above that Aristotle gets into difficulties by trying to maintain authority as a feature of political life despite rejecting Plato's contention that political authority is founded on natural inequality. I now suggest that Hobbes tries to justify a more decisive role for political authority (more decisive than the role Aristotle assigns it) by deepening and extending the egalitarianism of Aristotle's theory of citizenship. It must be recognized, however, that the problem of justifying authority presents itself in importantly different terms in the two theories. They agree that there is no natural basis for personal authority in political life. But Aristotle thinks the equality that excludes personal authority opens up the possibility of cooperative, mutually beneficial political interactions among citizens. Thus for him the question would seem to be why political authority is necessary at all; why should the values of unrestricted, fully equal participation be qualified in any way in the political realm? Insofar as he answers this question, he does so by arguing that rule through offices of authority and the laws they promulgate maximizes the influence of that human characteristic - namely, the capacity for rational self-rule-the possession of which distinguishes citizens from slaves, from women, and from barbarians. Law is "reason without passion" and rule by its means is thus rule by reason itself rather than rule by "men" in the sense of rule by creatures with a variety of characteristics in addition to reason. Authority qualifies but does not replace citizenship. Or as we might better put it, authority contributes to a politics of high citizenship by helping to insure that those human beings with the capacities necessary to citizenship act largely or primarily out of those capacities and not out of the characteristics that they share with noncitizens.

A variety of modulations on this theme achieved prominence in the later theory of the rule of law and of constitutionalism. But no such argument is available to Hobbes. He believes that the very equalities that forbid personal authority make human interactions conflictive and deeply destructive. The most notorious feature of Hobbes's theory of equality is his insistence that every person is vulnerable to being killed by any other. ${ }^{25}$ Equality in this raw

${ }^{25}$ Thomas Hobbes, Leviathan (Oxford: Basil Blackwell, I955), chap. I3. 
respect excludes the possibility that any of us will be able, by our own efforts, to assure our security. Natural equality excludes dominance on the basis of violence, power, and deception or manipulation as well as dominance on the basis of authority.

But it had scarcely been left to Hobbes to discover that human beings are rudely vulnerable to one another. The more interesting question that Hobbes addresses is why, in the absence of authority or some form of effective domination, personal security must be the constant, the overweening, human concern. Granting that others are physically capable of taking my life, why should they be disposed to do so? The explanation, Hobbes says, lies in the fact that human beings are equal in three further respects. First, although human interests and desires, purposes and objectives, vary in content from person to person, all human beings are interested and purposeful. ${ }^{26}$ Second, human beings share an environment in which the supply of resources necessary to satisfy their desires and achieve their objectives is inadequate to the demand for them. ${ }^{27}$ Third, and for present purposes most important, every person's well-being or satisfaction, as she defines or conceives them, are as good or deserving or legitimate as any other person's. ${ }^{28}$ There neither is nor can be any convincing reason why one person should sacrifice or subordinate her interests or objectives to those of anyone else. Equality in the first two respects guarantees that human beings will come into conflict; equality in the third respect excludes the possibility that the conflict can be contained or even moderated by the parties to it. Taken together, the three equalities exclude the possibilities that inform Aristotle's theory-namely, that equal citizens, acting in a setting of shared authority and law, can readily interact in a cooperative and mutually beneficial manner.

Ever in quest of parsimony and consistency, and finding uncommon delight in the intellectually arresting, Hobbes's solution to the problem is formed largely out of the very elements that constitute the problem itself. Individual interests and purposes remain of equal legitimacy, but with the crucial qualification that each and every one of them is subordinate to the one overriding interest-namely, avoiding the "contranatural dissolution" that prematurely terminates the pursuit of all interests and purposes. Persons who are

26Ibid., chap. 6.

27Ibid., chap. I3.

28Ibid., chap. 6. 


\section{Toward a Liberalism}

equal in the respects indicated, and hence equal in the further, supervenient respect that they know only the authority each exercises over herself, agree one with the other to create an office of authority to which they are severally and equally subject. The occupant of that office differs from others in no respect save that she is invested with the authority of the office. In particular, the interests and desires, the beliefs and values, the judgments and decisions, of the occupant of the office (qua natural person) possess no distinctive epistemic, moral, or prudential virtues or qualities. Subjects do not conform to the Sovereign's laws and commands because they approve of the content or the likely consequences of doing so. If, as Aristotle seems to assume, they could agree on (even in the sense of jointly recognizing once put before them) the merits of the laws and commands, laws and commands would be largely if not entirely superfluous. Subjects conform, rather, because the matters regulated by the laws and commands have proven to be the sources of intractable disagreement and mutually destructive conflict. In short, subjects obey the Sovereign for the same reasons that they created the office of Sovereign and made themselves its subjects-namely, to escape the horrendous consequences of their natural equality.

It would be no worse than a slight exaggeration to say that Hobbes's political theory seeks to "resolve" the difficulty of reconciling citizenship and political authority by eliminating citizenship and making relations in terms of authority the exclusive political relationship. Human beings as such may relate to one another in a wide variety of ways, but political persons, persons qua subjects, must relate to one another as subscribers to an office invested with authority. If they severally achieve the self-discipline necessary to maintain this thin but essential relationship, they may therefore find greater profit in their non- or extrapolitical relations; some among them may even hope to attain the felicity that consists in assurance of the more or less continuing satisfaction of their personal interests and desires and that is the highest estate God has permitted earthly humankind. ${ }^{29}$ If they fail in the requisite discipline, if they succumb to the temptation to pursue what Aristotle called the good life in and through politics and the political relationships of citizenship, they will succeed only in recreating-perhaps in a yet more dangerous form - their original predicament.

29Ibid. 
With these reflections-which some find dispiriting - in mind, I return to my earlier suggestion that arguments for authority have both a factual and an instrumental premise. The factual premise is that human beings are by nature equal in the several respects already discussed. This premise excludes personal authority. But it also opens the possibility of formal authority grounded in authorizations and yielding a distribution of obligations that is fair to all subjects. The premise that, despite the differences among their interests and purposes, all persons require security sufficient to allow them to pursue their interests, is an instrumental argument for accepting authority. If the condition specified by the factual premise is satisfied, the second premise implies that it is rational for each person to subscribe to authority in order to obtain the security.

This argument alters the specific form but does not resolve the generic character of the difficulties in Aristotle's theory. To restate them in the light of the intervening discussion, those difficulties consist in a tension between the factual premise of equality and the instrumental premise that some undeniable good or advantage is provided by authority. Using authority to pursue the good is problematic because doing so qualifies and encroaches on equality and the goods represented by it and served by respecting it fully. In abandoning the particular goods that Aristotle sees in equal citizenship, Hobbes renounces the attempt to reconcile authority and citizenship. But Hobbes's argument fails to resolve the closely analogous problem posed by his own recognition of equality. Is authority compatible with equality among (not citizens but) persons? Granted that all subjects have authorized the creation of the Sovereign, and granted also that they are equally subordinate to that office, there is an enormous inequality between the occupant of that office and each subject. And that inequality is at least as threatening to the values Hobbes treasures as authority is to Aristotle's values. Thus there is serious question whether Hobbes has made any progress toward justifying authority in a society of equals.

Hobbes's response to these objections depends heavily on two related ideas. The first is that the good sought by instituting authority has been reduced to minimal and incontrovertible proportions. The second is that the authority is formal or positional, not personal or substantive. The first point invites further comparison with Aristotle. The latter looks to politics-and hence in part to the authority that is an integral element of politics-for the highest (or perhaps 


\section{Toward a Liberalism}

the next to highest) and most complex aspects of the good for humankind. By contrast, Hobbes insists that each person must define and pursue her own good in her own way and he looked to politics and its authority to do nothing more than maintain a condition necessary to (but far from sufficient for) such private activity. By thus restricting the objectives of politics and its authority, by reducing those objectives to a common denominator on which all persons could be expected to agree, he hopes to make authority acceptable to all. As to the second point, Hobbes is of course aware that the office of authority will be occupied by a person or persons with the usual complement of passions and desires. He makes no attempt to deny that the occupant(s) of the office will use its authority in self-interested ways, and he firmly opposes all proposals to prevent such abuses by limiting or restraining the exercise of the authority of the office. (Hobbes prefers monarchy on the sobering ground that it reduces to the minimum the number of officeholders, thereby allowing satisfaction of the officeholder's personal interests at the lowest possible cost to the subjects. $)^{30}$ But he insists on a sharp distinction between the authority of the decisions of the office and the merits of those decisions. Subjects are to obey laws and commands not because they approve of or agree with their contents, but simply and exclusively because they are invested with authority. They are to obey authority because it is only when authority is obeyed that security can be maintained.

Hobbes's argument concerning the second point is of undeniable cogency and significance. To put the point in conceptual terms, if our sole reason for conforming our actions with laws and commands is our agreement with their content, we are acting on agreement or advice, not on obligation to authority. "Authority" and "law" are doing no work in our thought and action. Aristotle's argument that law is reason without passion, suggesting as it seems to do that citizens should obey laws because reason is embodied in them, confuses this point. Similarly, Rousseau's argument that in a politics of high citizenship "justice and utility may in no case be divided," 31 and indeed the assumption of the entire tradition of which he is a chief exemplar - that a politics of high citizenship will yield better law and policy than any other mode of politics-might be thought to involve the same confusion. In language that Hobbes

30Ibid., chap. 19.

31Rousseau, Social Contract, I, I. 


\section{Citizenship and Authority}

himself might have used, to take this stance would be to recreate the very difficulty that prompted the attempt to create authority. Authority cannot be the same as, cannot be equated with or reduced to, agreement concerning the substantive merits of policies or laws. Individuals and groups who disagree about the desired content of policies and laws cannot sustain political arrangements and relationships on the basis of agreement concerning that content. In a characteristically trenchant formulation, Hobbes says that "this device therefore of them that will make civil laws first, and then a civil body afterwards (as if policy made a body politic and not a body politic made policy) is of no effect." 32

Despite the seeming clarity of his understanding on this point, Hobbes does not in fact break the connection between the authority of laws and their content and purpose. His subjects create and obey authority in order to achieve what Michael Oakeshott calls an "imagined and wished-for" outcome or state of affairs-namely, peace and security. Agreement on the overwhelming importance of this objective is what explains and justifies the agreement to create and maintain authority. Accordingly, obedience to authority that does not in fact yield this outcome is irrational. Of course Hobbes urges subjects largely to forego judgment on this question. Except in those cases in which laws or commands themselves directly and unequivocally threaten the life of a subject, the subject is urged to let the Sovereign decide what will and will not conduce to security. But the logic of Hobbes's own argument prevents this from being more than advice, more than prudential counsel. Owing to the instrumental, end-oriented character of Hobbes's argument for authority and obedience to it, it is logically impossible for the authority of any law or command to be a sufficient reason for obeying it. Agreement on the proposition that peace and security are of paramount importance, and agreement on the further proposition that these laws and commands will yield peace and security here and now, is precisely what "makes" the Hobbesean body politic.

These considerations might tempt us to say that, appearances to the contrary notwithstanding, neither Hobbes nor Aristotle has a theory of authority. If it is a condition of such a theory that it make authority a sufficient, an invariably decisive, reason for action, then neither of these theories qualifies. This requirement is too stringent;

32Thomas Hobbes, Elements of Law (Cambridge: Cambridge University Press, I928), p. I 52. 


\section{Toward a Liberalism}

if we insist on it, authority among human agents becomes both a theoretical and a practical impossibility. Just below I develop this argument by examining Michael Oakeshott's more vigorous attempt to satisfy the requirement in question. Assuming in advance that I can make good on the contention I just advanced, a better way to describe my conclusions to this juncture is to say that neither Hobbes nor Aristotle succeed in eliminating the tensions that we first encountered in discussing Aristotle's theory. In both cases persons aware of their natural equality and concerned about sustaining the good represented by it must recognize that subscription to authority deeply qualifies the equality and puts the good it represents in serious and continuing jeopardy. They may nevertheless decide that, all things considered, the qualification and the jeopardy are preferable to the available alternatives. Hence they may make the authorization, engage in the subscription, requisite to the creation of authority. But extraordinary good fortune apart, some laws and commands will threaten the very values that induced them to subscribe to authority. Thus whether on the perhaps depressing Hobbesean assumptions about politics and political interactions, or on the more elevated and gratifying Aristotelian assumptions, authority may be tolerated and sustained but it can hardly be celebrated. Once the assumption that there is some inequality that (in company with an agreed objective) justifies authority was abandoned, it became impossible to arrive at an unproblematic theory of authority.

As I indicated at the beginning of this chapter, my own response to this circumstance is to recognize, or rather to insist, that political authority is a deeply problematic feature of our arrangements. Arguments for it are inescapably less than conclusive or dispositive, are irremediably vulnerable to objections that are not only cogent but powerful. To accept authority and authority relations as a feature of human arrangements is to make a dangerous compromise; it is to act contrary to beliefs and to risk values of the first importance. And because it is certain that there is no such thing as citizenship without authority, highly doubtful that there is any such thing as a political society without authority, it follows that accepting citizenship and political society takes on these same characteristics.

This conclusion might be thought to amount to the proposition that "human affairs are not all that one might have hoped" or 


\section{Citizenship and Authority}

perhaps "there is a tragic dimension to the human condition." Human beings cannot live together without political society and political authority, but salient and indeed highly valued characteristics of human beings should render both of these objectionable to them. This conclusion may be thought jejeune, trite, or at least morally and politically irrelevant. One can of course mount these objections against authority and citizenship, but pursuing them yields no program, no course of action, no even partial solution to the difficulties the recognition of which prompts the objections.

I suggest that reactions such as these are inappropriate. True, if the difficulties and objections I have been discussing are as general and as deeply grounded as I have suggested, they will not be entirely resolved or eliminated by awareness of them or by action informed by such awareness. But such an awareness may temper hopes, deflect quixotic initiatives, and contribute to the sobriety necessary if the difficulties are to be kept within tolerable proportions.

These perhaps unwelcome reflections presume what numerous theorists of authority and citizenship fervently deny, namely, that there are indeed insuperable theoretical and practical obstacles to overcoming the difficulties that have been my focus. So far from treating my objections as trivial or irrelevant, leading modern theorists of authority and citizenship have labored to overcome them. The conclusions I have just been anticipating would be justified only if their efforts could be shown to be unsuccessful.

The attempts that require consideration can be subsumed under the two broad categories that I have denominated Hobbesean and Rousseauist. The first seeks (in various ways) to render authority acceptable to political equals by limiting the activities, including the activities of citizens, of those who share in it. The second seeks to make authority effective in pursuing lofty ends and purposes by democratizing it radically, that is, by insisting that its possession and exercise be equally and continuously shared among all citizens who are within its jurisdiction.

\section{Michael Oakeshott}

I will focus my examination of developments in the Hobbesean tradition on Michael Oakeshott's attempt to achieve a purified version of an F-P theory of authority. I noted that Hobbes's theory maintains a vital connection between authority and an end or pur- 
pose alleged to be of overwhelming importance to all human beings. Hobbesean subjects authorize and subscribe to the authority of the Sovereign in order to achieve the peace and security that, in his judgment, can be attained in no other way. I argued, however, that this feature of Hobbes's argument puts authority in constant jeopardy. Rational subjects can be expected to maintain their subscription only insofar as doing so actually contributes to the end for which they instituted authority.

It is a major objective of Oakeshott's theorizing to secure the authority of political society against this jeopardy. He seeks to remedy this defect in Hobbes's theory by jettisoning the notion that political authority exists for the sake of achieving some end or purpose. In pursuing this objective, Oakeshott formulates a severely uncompromising version of the F-P theory of authority. As in all versions, the key notions (in addition to equality among those who subscribe to authority) are rules, offices, and procedures created by rules.

The authority of rulings and of administrative requisitions is recognized in terms of the rules which permit them to be made and which specify their jurisdiction. The authority of an office lies in the rules which constitute it and endow it with powers and duties and is to be recognized in terms of those rules. The authority of the occupant of an office lies in the rules which constitute it and endow it with powers and duties and is to be recognized in terms of those rules. The authority of the occupant of an office, his right to exercise its powers, is the license he acquires in coming to occupy it according to the rules of a prescribed procedure of appointment or succession. The authority of legislators to make, to amend, or to repeal ... [law] is recognized in the rules which specify the conditions to be subscribed to in order to occupy the office, and the ... [law] they declare is recognizable as authentic law in having been enacted in subscription to a prescribed procedure and in the exercise of powers conferred in this procedure. ${ }^{33}$

Rules are constitutive of authority: to understand authority is to understand rules; to subscribe to authority is to subscribe to and to know how to act in relation to rules.

Thus far Oakeshott's formulation differs from other F-P theories only in the single-minded, relentless reliance it places on the notion of rules. The special quality of his version, and its distinctive interest

${ }^{33}$ Oakeshott, On Human Conduct, pp. I 50-5I. 
for present purposes, resides in its insistence that the system of rules which constitutes political authority must be understood entirely without reference to desires and interests, ends and purposes, or even beliefs and values shared among those who make, enforce, and subscribe to those rules. The rules of civil authority are said by him to be purely "adverbial" in character; these rules speak exclusively to the manner in which individual citizens act on beliefs and values, pursue ends and purposes, to the choice of which authority, its rules, and the civil society they constitute are altogether indifferent. ${ }^{34}$ Speaking of rules of this kind, Oakeshott says: "A rule (and $a$ fortiori something less exacting, like a maxim) can never tell a performer what choice he shall make; it announces only conditions to be subscribed to in making choices." The criminal law "does not forbid killing or lighting a fire, it forbids killing 'murderously' or lighting a fire "arsonically." "The system of rules that makes up the practice of political authority in a civil society should be understood as "an instrument to be played upon, not a tune to be played." 35

It is not difficult to understand the motivation behind Oakeshott's development of this view. If the rules that constitute a practice of authority do not serve assignable interests or objectives, then it is impossible to decide whether to subscribe to them by deciding whether one approves the objectives they are intended to serve or by deciding whether in one's judgment the rules actually contribute to their intended objectives. Instrumental, utilitarian, or any other teleological reasoning is categorially and hence categorically excluded from the practice of authority. Members or citizens in a civil political association invested with authority relate to one another exclusively as subscribers to adverbial rules. For this reason, the question of whether they share ends or purposes, interests or objectives, beliefs or values, is irrelevant to whether they will be able to maintain authority. Or to put the point more positively, the common subscription to the procedural or adverbial rules that constitute political authority makes it possible for them to pursue their individual or group ends and interests, to sustain and act on their beliefs and values, without falling into destructive conflict.

${ }^{34}$ Ibid., pp. II6-I7. In this discussion I leave aside Oakeshott's importantly different account of authority in what he calls an "enterprise association" or universitas as opposed to civil association or societas. He develops the distinction between the two modes of association and their authority in the second and third essays of On Human Conduct.

35Ibid., p. 58. 


\section{Toward a Liberalism}

It should be noted that this understanding of authority accords an important place to, places a deep reliance on, something that might just as well be called citizenship. Citizens must maintain and act on, indeed are properly characterized by, a "disciplined imagination." There will be a standing temptation to use political authority to advance some substantive project or purpose, to achieve some anticipated and wished-for outcome. If a rule that contributes to such an objective can be invested with authority so that all citizens acquire an obligation to accept and obey it, then (as long as authority remains effective in commanding obedience) those who favor the objective will have materially advanced their cause. But to succumb to this temptation is to put authority and hence civil life in jeopardy. The turn to authority to pursue the objective indicates that there is disagreement concerning it, that those who favor the objective have failed to convince their fellow citizens of its merits. Investing a rule that serves the objective with authority adds nothing to the arguments for the objective itself. It asks, or rather purports to require, those who do not share it to accommodate themselves to it for some other reason-most likely to sustain authority. But there will be very good reasons for them to refuse to do so. In their view authority will have become a weapon in the service of the partisan objectives. To submit to it will be simply and straightforwardly to submit to a tyranny in the classical sense of rule in the perceived interests of the rulers and contrary to the perceived interests of the ruled. Thus citizens in the true sense are persons who understand the distinctions between adverbial rules on the one hand and substantive rules on the other and who act to assure that only the former are invested with the authority of the civil society.

This understanding of citizenship and its relationship to authority is directly relevant to the difficulties in that relationship that I have been considering. It is compatible with the essential features of the understanding that all citizens will participate in the offices that adopt and promulgate adverbial rules. (Which is not to say that Oakeshott himself favors a notably inclusive or democratized conception of citizenship, and it is certainly not to say that he favors active citizenship in the sense of a role that occupies large quantities of the time and energies of citizens.) Moreover, if authority is never used to pursue controversial or divisive objectives, there will be no instances in which subscription to it will qualify or compromise the equality, freedom, autonomy, or dignity of individual citizens. On. 


\section{Citizenship and Authority}

this understanding, the very fact that citizenship is inseparable from authority appears to mean that citizenship guarantees the equality that has been the supposition of theories of authority since Aristotle.

Oakeshott has given up on Hobbes's expectation that agreement could be achieved concerning the overriding importance of peace and defense, agreement sufficient to engender and sustain a stable and effective system of authority in a political society. In place of agreement on that (or, allegedly, any other) end or purpose, he proposes to substitute subscription to adverbial rules said to be indifferent to all ends and purposes. For reasons already considered, this proposal is both apposite and meritorious. Short of reverting to a fully Platonic conception of substantive-purpose authority, there can be no authority without distinctions between procedure on the one hand and substance on the other, between formal credentials and material desirabilities.

But Oakeshott's distinctions cannot do anything like all of the work he asks of them. A rule that prohibits killing "murderously" or lighting fires "arsonically" is a rule against murder or arson; it is a rule that prohibits a class of actions through the taking of which agents seek imagined and wished-for ends and purposes. Most generally, subscription to authority is itself human action and, as with all species of this genus, is done for a reason, to achieve some objective. ${ }^{36}$ If there is no agreement whatsoever concerning the objectives of subscription, the subscription can be maintained only by sacrificing equality among subscribers. A civil society on the Oakeshottian model might well diminish the conflict between authority and citizenship, but it could not eliminate that conflict. Although I will not be able to defend it here, I assert that the same is true of the numerous more mechanical devices proposed for the same purpose by other theorists in the F-P tradition.

\section{Rousseau and the Ideal of High Citizenship}

Oakeshott seeks to render authority and citizenship compatible by severely limiting the objectives or purposes of each. The limitations he seeks are to be achieved through understanding and selfdiscipline on the part of participants in civil society. They must

\footnotetext{
360akeshott himself gives us an excellent analysis of these features of human
} conduct. See ibid., esp. the first essay. 
appreciate what is distinctive about such a society and they must think and act in ways consonant with that appreciation. In this respect he differs from Hobbes and from most other thinkers who, like himself, have been concerned to limit the activities of those in authority. Hobbes relies on rulers to limit their own uses of their authority, looking to subjects primarily for obedience and for restraint in respect to the reasons for it. Others who have sought limitations on authority have placed little faith in either ruler or ruled, looking rather to a variety of devices such as constitutions, bills of rights, divisions of authority of various kinds, countervailing forces in society, and so forth. In the perspective given by these comparisons, we might even characterize Oakeshott as a theorist of high citizenship.

Writers in what I have called the Rousseauean mode nevertheless firmly reject Oakeshott's outlook. Citizens may play a role in his conception of civil society, but that role is woefully limited, woefully negative in character. Citizens act to protect their equality as individuals; they act to prevent political society from imposing collective goals and preferences on individuals who do not share them. This of course means that political society will almost certainly be debarred from acting to eliminate the innumerable and highly destructive inequalities that coexist with the essential but unsatisfactorily thin equality that obtains among its members by virtue of the fact that they are human agents. More important, it means that citizenship is not a role in and through which individuals pursue, in company with one another, the moral excellences (however encompassing) of which they are capable. For Rousseau the theory and practice of authority and citizenship takes "men as they are" but seeks to achieve "laws as they might be" in order not only that "justice and utility may in no case be divided" but that man's "faculties" will be "so stimulated and developed, his ideas so extended, his feelings so ennobled, and his whole soul so uplifted" that he attains to a "moral liberty." 37 For Oakeshott, the objective of the theory and practice of citizenship and authority is to take human beings as they are-and leave them that way.

Crucial to the position of Rousseau and his followers are a pair of assumptions that at least appear to be highly plausible. The first of these is that the possession and exercise of authority enlarges and

37Rousseau, Social Contract, I, viii. 
enhances one's capacity for effective decision and action. To possess the authority to do $X$ is to have a kind of right to take that action. It is to have a warrant for doing $X$ that is established in one's community, a warrant that other members of the community have an obligation to respect. Thus acquiring authority is in principle equivalent to eliminating or freeing oneself from a whole array of limitations on and obstacles to action that might be posed by the objections of other parties. The latter might disagree or object, but they are bound by their subscription to go along or stand aside. The second assumption gives a communal or collectivist cast to the first. At bottom it is the notion that authority will not be objectionable to those who possess and exercise it. If a system of authority enhances the possibility of effective action, and if we exercise authority under that system, then we should welcome the system of authority.

The objections to authority, in other words, always, and reasonably enough it would seem, come from those who do not have it. From these assumptions there is drawn what seems to be the impeccable inference that authority could be made welcome to all by the device of extending its possession and exercise to the entirety of those who make up the community in which it is established. If each and every member of the community participated fully in the possession and exercise of whatever authority is established in it, the efficacy of collective action would be enhanced and no member would have reason to complain about either the existence or the use of authority. If authority is thoroughly democratized, it becomes acceptable in a society of equals. More positively, by virtue of their status as members of the citizenry, each citizen is in the attractive position of possessing and exercising authority, and hence the attractive aspects of both citizenship and authority complement rather than conflict one with the other.

Of course no proponent of democratized authority and/or high citizenship has ever seriously envisaged distributing authority to all members of any political society. The assumption of political equality has without exception been withheld from children and from certain classes of criminals and those judged to be mentally deficient or deranged, and it has been extended only hesitatingly and grudgingly to those of alien religious conviction, to the unpropertied, and above all to women. These large qualifications aside, from the perspective of this essay much of the theory of high citizenship can be viewed as taking a highly favorable attitude toward authority 


\section{Toward a Liberalism}

and attempting, through citizenship, to extend the supposed benefits of its possession and exercise. Whereas the line of thought running from Hobbes to Oakeshott views authority as contributing certain essential but narrowly confined advantages, the Aristotelian and more especially the Rousseauean tradition looks upon it as, potentially, a highly desirable feature of human affairs. If authority is suitably arranged and distributed, those who possess and exercise it can be ennobled by the experience. ${ }^{38}$

The key assumption that political authority enhances individual and collective action seems to be challenged by much of our experience with systems of authority. Systems in which authority is firmly established, seldom if ever resisted or challenged, are nevertheless characterized by dispute and division, often by deadlock that is broken, if at all, by compromises satisfying to no one. Rather than facilitating action, the existence of established political authority motivates and organizes opposition to it.

Rousseaueans are likely to argue that this evidence, although abundant, is irrelevant to their argument because it is as it were an artifact of the very views that their argument confutes. Those who have failed to appreciate the potential advantages of political authority, those whose thinking is dominated by experience with authority improperly arranged and distributed, have deliberately incapacitated the systems of authority in or under which they live. The claims of the Rousseauean theory can be tested only in systems that have eliminated artificial limitations on and complications in the exercise of authority and have established an organic connection between authority and high citizenship.

It will be instructive to pause here to note points of agreement between Hobbes and the Rousseaueans. At least as concerned as the latter with the efficacy of authority, Hobbes argued that it would be maximized where (a) its scope and (b) its location or possession were as little in doubt, as little subject to debate, as could be. Dispute about (a) would be excluded by making the authority of the Sovereign unlimited, without qualification of any kind, the solution Hobbes comes very close to adopting. So far as Hobbes can see, dispute about (b) can be eliminated by investing all authority in one person and by treating that person as "representing" all those over

${ }^{38}$ For suggestive reflections that bear on this theme from a somewhat different angle of approach, see Nannerl Keohane, Philosophy and the State in France (Princeton: Princeton University Press, 1980), esp. her interpretation of Rousseau as continuing and in a sense completing the tradition of absolutist thought in France. 
whom the authority is to be exercised; it can be kept minimal by investing it in a small number of persons also treated as "representing" all of the others; or it can be maximized by distributing it throughout the populace (making, of course, unavailable the valuable notion of representation). Hobbes of course favors the first over the second and abhors the third.

Hobbes's handling of $(a)$ is often and on the whole correctly attributed to Rousseau himself and to other recognizably Rousseauean positions. Without going into controversial exegetical details, theorists of high citizenship hope for too much from authority to allow them to be comfortable with notions of constitutional, institutional, and other limitations on it.

As to (b), Rousseaueans also share Hobbes's concern with plurality, diversity, and conflict among the possessors of authority. Of course they must reject monarchy (albeit there is the Legislator!), aristocracy (albeit there are the noncitizens!), and all notions of representation that permit one party or set of parties to act on behalf of-that is, in place but in the name of and in a manner binding on-another party of parties. In fact, therefore, a Rousseauean polity necessarily distributes authority in what Hobbes thinks is the worst possible way-that is, among a great many individuals each of whom, by virtue of occupying the office of citizen, can do as she wishes with her measure of political authority. How, then, are confusion and stalemate to be avoided, efficacy of action to be achieved?

Despite the obvious differences between Rousseau and Hobbes, commentators concerned with this question have discerned in Rousseau and other theorists of high citizenship notions akin to the "unity" that Hobbes claims is produced when Leviathan is created by the "authorization" of its "subjects." 39 But Rousseau's rejection of representation means that this unity can not be "artificial" in the sense of Hobbes's "unity of the representer, not the unity of the represented." 40 For this reason, and perhaps owing to the prominence of obscure notions such as general will in theories of high citizenship, it has frequently been suggested that the desired "efficacy" would be achieved at the expense of plurality and individuality-that is, by fostering an all too "real unity" consisting of stultifying conformism maintained by democratic tyranny.

${ }^{39}$ Hobbes, Leviathan, chap. I7.

40 Ibid., chap. I 6. 


\section{Toward a Liberalism}

We should note at once that a requirement of some degree of consensus, of broad if not unqualified agreement on at least some matters, is a feature of any theory of authority and any theory of citizenship. Even Hobbes and Oakeshott, who are as anxious to minimize this requirement as any thinkers known to me, recognize that the requirement must be satisfied in some measure. As a bare minimum, there must be agreement that this and not that is an office invested with authority, that these and not those are the rules and procedures by and through which authority is exercised. But even this much agreement cannot be achieved or sustained unless there is also something close to consensus on some number of further values and beliefs. For Hobbes, peace and security must be accorded overweening importance and there must be a shared belief that they can be achieved and maintained only if there is political authority. For Oakeshott the comparable value seems to be the desirability of "abating" somewhat the "contingency" that conditions all human conduct, ${ }^{41}$ this objective or value being conjoined with the belief that contingency is best abated by fidelity to an adverbially defined civility constituting a practice of authority. I elaborate somewhat on this point below, but it is manifest that to criticize the ideal of high citizenship for supposing consensus on something is frivolous if not captious.

Second, it would clearly be a mistake to interpret the major theorists of high citizenship as presuming deep and extensive consensus. They do presuppose the degree of commonality represented by acceptance of the natural moral equality that forbids a politics of personal authority. They argue, however, that further and more substantive commonalities will develop in the course and as a consequence of a life of shared citizenship. Citizenship is a remedy for the fragmentation, division, and conflict that exists in its absence. Rousseau's work is especially striking in this regard, containing both biting denunciations of the selfishness, competitiveness, and antagonism rife in his society and paeans to the mutuality that could be expected if Frenchmen became genuine citizens. The same contrast between reality and potentiality is sharply drawn by contemporary theorists of high citizenship such as Arendt, Barber, and Pateman. Whether inspired by classical city-states, eighteenth-century Geneva, Swiss cantons, or Yugoslavian factories, these theorists describe high citizenship as a kind of bootstrap operation;

${ }^{41}$ Oakeshott, On Human Conduct, p. I80. 


\section{Citizenship and Authority}

active, continuing involvement in the life of a suitably organized political association will itself create such commonalities as are necessary to politics in this mode. To the objection that their ideal is irrelevant because the conditions of its realization are nowhere satisfied, they rejoin that serious pursuit of the ideal will itself create those conditions.

Third, there is no reason to think that there is any very large inventory of items on which consensus is specifically required. The scope of the consensus that is expected varies depending on the theorist's conception of the aspects of life that are fit subjects for political deliberation and interaction. There is, for example, no need for Aristotelian or Arendtian citizens to agree on the principles of a household economy. Critics who represent the ideal as requiring or aspiring to an encompassing uniformity simply misrepresent it.

These interpretations can be restated to give a better focus to the question of whether high citizenship contributes distinctively to easing the authority-citizenship relationship. The theory of high citizenship presents an ideal that is primarily procedural. It does not celebrate political outcomes or states of affairs-for example, those in which everyone agrees with the substance of all decisions, or those in which everyone ought to agree because the decisions are correct, just, or otherwise meritorious. True, some proponents of the ideal have believed that decisions made by an active citizenry will, as a generalization, be better decisions better supported. If true, these generalizations provide ancillary support for the kind of politics the theory promotes. But it would be imprudent to argue for high citizenship primarily on these grounds, even less prudent to argue that citizens should obey laws for these reasons. The first argument tends either to make authority irrelevant or to disqualify citizen involvement wherever the generalization fails to hold. On the second argument authority becomes equivalent to that about which consensus obtains and hence is again either superfluous when available or unavailable when needed.

In its most persuasive formulations, then, the theory of high citizenship favors a particular kind of political process because it generates and sustains distinctive characteristics and attitudes among the citizenry. Perhaps the most appropriate general term for the characteristics and attitudes the theory hopes to engender is identification: self-identification as citizen and shared identifications as members of a citizenry pursuing the good of the collectivity 


\section{Toward a Liberalism}

of citizens. In place of fragmenting, conflict-generating attitudes such as self-interestedness and competitiveness, it encourages cooperation and trustful acceptance of interdependencies. As sharers in the authority of the polity, citizens engage in deliberations addressed not to the question of which interests will prevail (albeit most decisions will in fact benefit some interests and disserve others) but what they as conjoint authorities should best do. They are to think of authority not as a weapon to be fought over but as a communal asset to be wisely used.

As citizens develop these characteristics their disagreements become "friendly" in the sense of a "friendly amendment" to a motion, one offered in the spirit of a contribution to a common enterprise. Thus those who oppose proposals, who argue and vote unavailingly against them, can not only accept but identify with their adoption. They can do so not only because they have participated in the process that yielded that outcome but because they identify with the spirit that animates it and with the enterprise of which that spirit is the vital center.

Understood in this manner, high citizenship is more than an attractive ideal. It captures qualities that are, in some measure, almost certainly indispensable to any encompassing, politically organized association. Most pertinent here, it specifies features without which no such association could develop or sustain authority. Authority is a kind of reason for action: to acknowledge the authority of a rule is to acknowledge that there is a reason for conforming to it. But it is a reason of a very special kind. Although it cannot be entirely divorced from the content of the rules in which it is invested, neither can it be equated with or reduced to the merits of those rules. It is therefore a conceptual as well as a practical impossibility to sustain subscription to authority in the absence of considerations-including considerations in addition to assessments of the substantive merits of the rules-which support the judgment that the authority of a rule is a reason for obeying it. In the entire absence of identifications of the kinds promoted by the theory of high citizenship such considerations would be unavailable.

Should we not enlist ourselves in the cause of high citizenship?

\section{Conclusion: Citizens and Individuals}

My own answer to this question is a qualified negative. It is negative primarily because the ideal of high citizenship accommo- 


\section{Citizenship and Authority}

dates itself too readily to political authority. Stated somewhat ironically, my answer is negative primarily because the theory of high citizenship is too successful in the task that I, in company with some of its most distinguished proponents, set for it, the task of reconciling citizenship and authority.

Early in this essay I argued that citizenship is inseparable from authority. I then asked whether this is reason to be suspicious of citizenship as well as of authority. The theory of high citizenship returns a negative answer to my question. It encourages citizens to identify with authority.

This response has its share of attractions. If authority became what the ideal of high citizenship portrays it to be, why shouldn't we as citizens identify with it? It is of course appropriate to be wary of authority in conflict-ridden societies in which authority is paternalistic at its best and tyrannical at its more usual worst. Because these have been and continue to be the circumstances of most human beings, resistance to the alternative understanding proposed by the theory of high citizenship is more than understandable. Unfortunately, that resistance perpetuates the very circumstance that prompts and sustains it. Authority will cease to be suspect only when we create for ourselves a politics of high citizenship in which we no longer have reason to suspect it.

In my judgment, however, authority is on principle suspect, on principle objectionable. It is more objectionable under some circumstances than others, but it is always objectionable. The reasons it is always objectionable can be stated in a number of ways and could take us into a moderately technical literature. ${ }^{42}$ At bottom, its objectionable qualities reside in a fact we have encountered several times, namely, that (certain special cases aside) it has a role to play only when we disagree concerning the merits of the actions we should and should not take, the policies we should and should not adopt. Where there is consensus concerning what should and should not be done we simply act or refrain from acting on reasons specific to the actions in question. But if we disagree or are uncertain (but nevertheless judge that a decision must be made) authority may be invoked as a reason for accepting a particular decision. Thus as a

\footnotetext{
42See, for example, Richard B. Friedman, "On the Concept of Authority in Political Philosophy," in Flathman, Concepts in Social and Political Philosophy; Joseph P. Raz, Practical Reason and Norms (London: Hutchinson, 1975) and "On Legitimate Authority," in Philosophical Law, ed. Richard Bronaugh (Westport, Conn.: Greenwood Press, I978).
} 


\section{Toward a Liberalism}

logical matter (the psychology of the situation may of course be less clear-cut) either authority has no work to do or it works to give us a reason for an action that we would not otherwise (that is, in the absence of authority) take. To subscribe to authority is to commit oneself to take actions that one would not take if considered exclusively on the merits of the actions themselves. ${ }^{43}$ Under suitable circumstances, there may on balance be convincing reasons for such a commitment; I at least do not see how a reflective person could make that commitment without regret.

Neither the theory of high citizenship nor any other theory alters this characteristic of authority. Insofar as action is taken in the absence of consensus, or is continued after that consensus has disappeared, some citizens will be required to accommodate to policies with the content of which they disagree. If or insofar as the idea of high citizenship is realized, however, this fact will not so much as give them pause; they will not find it objectionable or even mildly regrettable. Having come to identify themselves as citizens and hence as sharers in authority, when a decision has been made they will focus not on its content but on the fact that authority of which they are a part has made it. Identifying themselves as they do with authority, they cannot regard that which is invested with authority as infringing on or derogating from them.

The politics of high citizenship may begin in plurality and disagreement, but (insofar as it acts in a determinate manner on any specific question) it must end in unchallengeable agreement (concerning that question). But of course agreement cannot alter (what as likely as not will be) the fact that there are excellent reasons against the decision or policy. In short, the politics of high citizenship would not change the fundamental character of authority; it would change the attitudes of citizens toward authority. ${ }^{44}$

\footnotetext{
${ }^{43}$ More precisely, it is to commit oneself to the proposition that one may (if authority is in fact invoked) acquire obligations to take actions that one would not take on their merits. The obligation, of course, need not be regarded-in my judgment, ought not to be regarded-as an invariably decisive reason for action.

${ }^{44}$ Much of this argument can be abbreviated by reference to the complications mentioned in n. 43, above. If we regard the obligation to obey authority as less than an invariably decisive reason for action, we in effect open up space for civil disobedience. If I have correctly construed the ideal of high citizenship, in a politics that fully realized that ideal civil disobedience could never be justified. Or rather, civil disobedience would be both a logical and a psychological impossibility. I have argued elsewhere that a defensible theory of political authority must provide a place for justifiable civil disobedience. See my Practice of Political Authority, pt. II.
} 


\section{Citizenship and Authority}

I said that my answer to the question "Should high citizenship be our ideal?" is a qualified negative. It remains to say something about why, from the perspectives of this essay, the negative is qualified, about why our attitude toward citizenship and politics should be chastened not withdrawalist.

I argued that Plato's theory is incoherent because it relies on an authority while denying a condition thereof, that is, denying the availability of persons who are not themselves authorities but who have sufficient knowledge or understanding to accord that standing to others, to recognize and acknowledge the authority of the pronouncements or performances of others. This argument can be restated as follows: Plato makes unintelligible the relationships among authority, its pronouncements and performances, and those to whom those pronouncements are addressed (for whom they are to bear authority or be authoritative).

Although typically (not invariably and seldom clearly) employing the concept of in authority, withdrawalist and "low" citizenship theories are in constant danger of an analogous incoherence (and its practical consequences). The characteristic pronouncements or performances of in authorities are laws and commands promulgated to those who have authorized or otherwise subscribed to the system of authority in question (who are in the jurisdiction of that system of authority). With the qualification that they depersonalize authority by making it a property of offices and rules, these theories claim (as in Hobbes and Oakeshott) or tacitly allow (as in much of the "low" theory of citizenship) that there is an intelligible relationship among the three elements analogous to those that compose an authority relationships à la Plato, that is, offices invested with authority, laws and commands issuing from those offices, and the citizens or subjects to whom the laws and commands are promulgated. If those laws and commands are intra vires, that fact about them is said (by these and numerous other theories) to create-or rather to constitute-an obligation, the obligation of obedience to the laws and commands, for everyone in the jurisdiction. For present purposes let us concede (what deserves challenge) that abstractly (conceptually) these relationships are intelligible.

Insofar as they are successful in discouraging the interactions between officeholders and citizens or subjects, withdrawalist and low citizenship theories reduce the relationships in question to the terms just stated, that is, they reduce "politics" to authority, law, 


\section{Toward a Liberalism}

and to the obligation of obedience. While all forms of "legal absolutism" and numerous explications of in authority construe the obligation to obey as independent of the merits of laws, these theories go further and argue that citizens or subjects should disavow (as in Hobbes) or suppress to the greatest possible extent (as in most of the theories cited in note $\mathrm{I}$, above) concern with the reasons for or merits of laws and commands. It may be (as in Hobbes but rarely in other theories of political withdrawalism and low citizenship) deemed valuable for them to understand why authority and law are necessary, but it is not valuable, may be harmful, for them to consider or even to be made aware of the reasons for and against the adoption (as distinct from the enforcement once adopted and until repealed) of this, that, or the next law.

The strongest formulation of the argument I am advancing against these theories (strongest, that is, if we continue to assume the intelligibility of the conceptual relationships discussed just above) is that this position is incoherent because citizens and subjects who do not understand the reasons for a law cannot discharge their obligation to obey it; they cannot do so because knowing what counts as obeying a rule, knowing what the rule demands or forbids, requires understanding the reasons for it. Although I think there is a convincing version of this argument, because presenting it here would take us far afield, I instead make the (for present purposes sufficient) arguments that (a) such an understanding is often necessary to knowing how to obey (or disobey) a rule and (b) that in any case in the absence of such understanding the occurrence of obedience or disobedience becomes random, ceases to be explainable and to that extent expectable in terms of thought and action within politics.

This charge, frequently stated in terms of volatility or a tendency to lurch from sullen but otherwise lifeless submission to destructive disorder, is often brought against, as it were, the other side of the equation, that is, against authoritarianism and the unwillingness of authoritarian rulers and their apologists to justify or even explain the reasons for their laws and commands. By eschewing or discrediting concern with and involvement in the political processes that produce laws and commands, withdrawalism and theories of low citizenship make it difficult if not impossible for those subject to authority to augment or enrich the (at best) thin intelligibility of their relation to political authority as such by an understanding of 


\section{Citizenship and Authority}

the reasons for and against the laws and commands they are expected to obey.

Stripped of what is often their arrogant and aggrandizing moralism and perfectionism, the promise of theories of high citizenship is that they will eliminate this randomness, will give intelligibility and the possibility of stability to the relationship between political authority, law, and obedience and disobedience. For the reasons I have given, this promise is worse than false. There is no unproblematic theory of authority, no sure way to maintain intelligibility-let alone yet more attractive or satisfying connections-among the components of authority relationships. But as programs for public life, withdrawalism and low citizenship give up on the attempt to sustain these relationships in so much as a tolerable condition. ${ }^{45}$

There is no formula for making political life tolerable, but there are two languages that may assist us as we make the continuing and inherently problematic effort to do so. The more prosaic of these features the distinction between persons-or better, individualsand their statuses and roles. "Citizen" is one status (office) that most of us occupy, citizenship one of the roles that we play. As individuals we are also parents, plumbers, and professors, consumers, co-workers, and colleagues. As individuals, one of our concerns is to try to understand and maintain in a satisfactory condition the relationships among our several statuses and roles. Doing so requires something by no means easy to achieve or maintain, that disciplined imagination of which Michael Oakeshott has written. Theories of high citizenship privilege the status and role of citizenship at the expense of all others (and of individuality); theories of low citizenship privilege all others at the expense of citizenship (and the protections and other advantages that it, properly understood, can afford to individuality).

Our self-awareness as individuals may afford critical perspective on the several partial and more specialized roles that we play, including the role of citizen. As Aristotle's sometimes poetic discus-

45I say programs because theories of politics, that is, attempts to theorize the present form of human association which is both encompassing and coercive, must maintain accommodations for individual and group exceptionalism and idiosyncrasy. But individuals and groups who want to universalize or even generalize their withdrawalism are obliged, it seems to me, to adopt philosophical anarchism. Nothing in this essay is intended to discredit or diminish the immense attractiveness of the latter view. 


\section{Toward a Liberalism}

sions of the relationship between a good man and a good citizen may also be interpreted as suggesting, such perspective may allow us to understand that citizenship implicates us in the perhaps necessary but nevertheless objectionable mode of relationship that is subscription to political authority. Such an understanding yields no argument for withdrawing from citizenship and politics, a course that could put our individuality and hence all of our roles in jeopardy. It does give us reason to conduct ourselves as citizens in a manner befitting our individuality; it gives us reason to adopt a chastened view of citizenship. 